\title{
SEED LONGEVITY CHART TO PREDICT VIABILITY OF CORN SEED DURING OPEN STORAGE
}

\author{
CLAUDINEI ANDREOLI ${ }^{1}$ e RAMIRO VILELA DE ANDRADE ${ }^{2}$
}

\author{
IResearcher, Embrapa Soja, Caixa postal 231,CEP.86001-970 Londrina,PR Brazil, andreoli@cnpso.embrapa.br \\ (Corresponding author) \\ ${ }^{2}$ Researcher, Embrapa Milho e Sorgo, Caixa postal 151, CEP. 35701-970 Sete Lagoas, MG
}

Revista Brasileira de Milho e Sorgo, v.6, n.2, p.247-255, 2007

\begin{abstract}
The simplified equation $V t=V i-\operatorname{tg} \beta . p$ is to predict the percentage of viability of any corn (Zea mays L.) seed lot after any period of time under open storage conditions. Based upon that equation, the objective of this work was to set a practical seed longevity chart to predict viability of corn seed lot during storage. From data of five corn seed lots stored at Sete Lagoas, MG, the value of the storage index $(\sigma)$ was calculated. This value ( $\sigma=120$ days) corresponded exactly to the time taken in days for the initial germination of corn seeds stored to fall to a certain germination value observed in the accelerated aging test. Once the storage index $(\sigma)$ is estimated, the viability chart which illustrates the relationship between initial germination, seed deterioration rate and storage condition over time can be constructed. The chart can be used by any seed producer once the value of storage index $(\sigma)$ in situ is determined. The application of the seed viability chart to short-term seed storage seems to be promising for seed growers. This predictive model is the first attempt of incorporating the effect of seed quality, the deterioration rate and the storage environmental conditions (temperature and relative humidity) into a seed longevity chart of an open storage.
\end{abstract}

Keys words: Zea mays (L.), seed deterioration, aging, germination.

\section{GRÁFICO PARA PREDIÇÃO DA VIABILIDADE DA SEMENTE DE MILHO DURANTE O ARMAZENAMENTO CONVENCIONAL}

RESUMO - A equação simplificada $V t=V i-\operatorname{tg} \beta . p$ foi desenvolvida para predizer a perda da viabilidade de semente de milho (Zea mays L.) em armazém convencional. Com base nessa equação, o objetivo deste trabalho foi desenhar um gráfico prático de longevidade da semente, para predizer a viabilidade dos lotes de semente de milho durante o armazenamento. Cinco lotes de milho híbrido BRS 201 foram armazenados nas condições ambientais de Sete Lagoas, MG, e o valor do índice de armazenamento $(\sigma)$ foi calculado. Esse valor $(\sigma)$ de 120 dias corresponde ao tempo que a semente levou para sua viabilidade inicial cair a uma certa porcentagem de germinação, no teste de envelhecimento acelerado, para os lotes de milho. Uma vez que o índice $(\sigma)$ é determinado, o gráfico de longevidade pode ser construído, o qual ilustra a relação entre a germinação inicial, a taxa de deterioração e as condições do armazenamento. Aplica-se o gráfico com informações úteis, desde que o valor do índice de armazenamento seja calculado para as condições in situ do seu armazém. A aplicação do gráfico de longevidade para médio prazo de armazenamento é promissora para os produtores de sementes. Esse mo- 
delo predicante é a primeira tentativa de incorporar o efeito da qualidade da semente, a taxa de deterioração e as condições de armazenamento convencional num gráfico, para predizer a longevidade da semente.

Palavras-chave: Zea mays (L.), deterioração da semente, envelhecimento, germinação.

There are many circumstances in which it is important to predict the effect of the environment on the longevity of seeds, especially in relation to the very rapid loss of viability and vigor that usually occurs under tropical conditions. Seedsmen and seed conservationists are interested in slowing down the loss of viability in seed storage for genetic banks. More often, seed producers wish to predict the longevity of their marketable seeds. Thus, corn and soybean are commonly stored only from harvest in the fall until sowing in the following spring; nevertheless, seed producers have expressed interest in short-medium term storage periods. In general, when seeds are stored at high temperatures or high seed moisture levels, the germination percentage declines more rapidly than when seeds are stored under cooler and drier conditions (Burris, 1980).

The accelerated aging test has been used to estimate seed vigor and deterioration during storage (Delouche \& Baskin, 1973). However, this test does not account for the effect of seed moisture and temperatures during storage. For this reason, seed viability equations which incorporate the effects of storage temperatures and seed moisture have been developed for many species (Roberts, 1960, 1961, 1973; Abdalla \& Roberts, 1968). The improved model of seed deterioration is relatively accurate at constant temperatures and seed moisture content. However, most seed crops that are stored in warehouses are not normally exposed to constant environmental variables. Lately, Tekrony et al.
(1993) proposed a model using Ellis \& Roberts' (1980) equation to predict changes in soybean seed deterioration in an open warehouse. This predictive model, despite offering potential for predicting seed deterioration under warehouse storage condition, has the disadvantage of recording and applying monthly the climatic data on the equation. A fast, simple and accurate prediction of seed viability under changing environmental conditions would be of a great value to seed producers.

\section{The basic viability equations}

Three factors are of fundamental importance in controlling seed deterioration seed moisture, temperature and initial quality. Seeds have been classified into orthodox and recalcitrant (Roberts, 1973) according to their response to water and desiccation. The longevity of orthodox seeds is prolonged by a reduction in water content and temperature (Roberts 1960, 1961). The frequency of individual deaths in time of a population of seeds stored under constant conditions is described by a normal distribution:

$$
y=\{1 / \sigma \sqrt{(2 \pi)}\} \exp \left\{-(p-\mu)^{2} / 2 \sigma^{2}\right\}
$$

where $y$ is the relative frequency of death occurring at time $p, \mathrm{~m}$ is the mean viability period and $\mathrm{s}$ is the standard deviation of the distribution of deaths in time. The relationship between moisture content, temperature and mean viability period is described by the following equation:

$$
\log \mathrm{p}=\mathrm{K}_{\mathrm{v}}-\mathrm{C}_{1} \mathrm{~m}-\mathrm{C}_{2} \mathrm{t}
$$


where $m$ is the moisture content (per cent), $t$ is the temperature ( $\mathrm{o}$ ), and $\mathrm{K}_{\mathrm{v}}, \mathrm{C}_{1}$ and $\mathrm{C}_{2}$ are constants. Thus, to predict the percentage viability of a seed lot after any period of storage, the four viability constants need to be determined.

\section{Improved basic viability equations}

As seed survival curves conform to negative cumulative normal distributions [Equation (1)], each curve may be quantified by the mean viability period, $p$, measured in days and the standard deviation of the distribution of deaths in time, $\sigma$. Ellis et al. (1991) have shown that, within a species, the constant values $\mathrm{C}_{1}$ and $\mathrm{C}_{2}$ are not affected by either the genotype and/or the seed quality. If these constants and $\sigma$ are independent of genotype and seed quality, then the value of $\mathrm{K}_{\mathrm{v}}$ must also be independent of these factors (Ellis \& Roberts, 1980).

Following these arguments, Ellis \& Roberts (1980) proposed an improved viability equation:

$\mathrm{v}=\mathrm{Ki}-\mathrm{p} / 10 \mathrm{~K}_{\mathrm{L}}-\mathrm{C}_{1} \mathrm{~m}-\mathrm{C}_{2} \mathrm{t}$

where

$\log \sigma=\mathrm{K}_{\mathrm{L}}-\mathrm{C}_{1} \mathrm{~m}-\mathrm{C}_{2} \mathrm{t}$,

This equation relates probit percentage viability, $v$ at any time $p$, to any combination of moisture content, $m$ and temperature, $t$. Three of the constants $\mathrm{K}_{\mathrm{L}}, \mathrm{C}_{1}$ e $\mathrm{C}_{2}$ are specific to the species, but independent of genotype and initial seed quality. Extreme storage conditions place limits on the applicability of the improved equations. For these reasons, they conclude that the following equation describes the relationship between seed longevity in barley and the storage environment over a wide range of conditions: $\log \sigma=\mathrm{K}_{\mathrm{E}}-\mathrm{C}_{1} \operatorname{logm}-\mathrm{C}_{\mathrm{H}} \mathrm{t}-\mathrm{C}_{\mathrm{Q}} \mathrm{t}^{2}$

For application to normal storage conditions, the improved viability equation (3) is appropriate, but for a wider range of storage conditions the following equation, is recommended:

$\mathrm{v}=\mathrm{Ki}-\mathrm{p} / 10 \mathrm{~K}_{\mathrm{E}}-\mathrm{C}_{1} \log \mathrm{m}-\mathrm{C}_{\mathrm{H}} \mathrm{t}-\mathrm{C}_{\mathrm{Q}} \mathrm{t}^{2}$

\section{Simplification of seed viability equation}

It follows from equation (1) and (2) that seed survival curves (percentage viability plotted against time) are cumulative normal distributions of negative slope, which become straight lines if the percentage values are transformed to probit. In such plots the slope of the curves is given by $1 / \sigma$ (Finney, 1971), thus Andreoli (1998) proposed a new simplified model as it follows:

$$
\mathrm{V}_{\mathrm{t}}=\mathrm{V}_{\mathrm{i}}-(\operatorname{tg} \beta) \cdot \mathrm{p}
$$

where the slope $t g b$ from equation (7) is a direct measure of the slope $(1 / \sigma)$ of the seed survival curves, therefore $\operatorname{tg} \beta$ is the seed deterioration rate of under any specific storage environment expressed by the angular coefficient of the survival curve, which corresponds to $10 \mathrm{~K}_{\mathrm{E}}$ - $\mathrm{C}_{1} \operatorname{logm}-\mathrm{C}_{\mathrm{H}} \mathrm{t}-\mathrm{C}_{\mathrm{Q}} \mathrm{t}^{2}$ of Ellis \& Roberts' (1980) equation. Neither genotype nor seed quality affect the slope $(\operatorname{tg} \beta)$ of the simplified viability equation (7); it is only the intercept, $\mathrm{V}_{\mathrm{i}}$, of the survival line which is affected by such factors (Andreoli, 1998; Ellis \& Roberts, 1980).

The objectives of this work were: a) to test the simplified viability equation for corn seed lot and, b) to determine the storage condition $(\sigma)$ in order to construct a seed longevity chart for 
predicting changes in germination of corn during warehouse storage.

\section{Material and methods}

\section{Storage treatment}

Five seed lots of corn double hybrid BRS201 were stored in an open warehouse at Embrapa Milho e Sorgo, Sete Lagoas, in the State of Minas Gerais. Each seed lot was conditioned, dividing into three replications and sub-dividing into $2 \mathrm{~kg}$ sub-samples, which were placed in multi-wall paper bags ( $20 \mathrm{~kg}$ capacity), which are normally used by seed companies. The multi-wall paper bags in each replication were stacked on a pallet at the experimental site in the warehouse. The pallets were placed in the center of the warehouse on 4 July 1998.

An initial seed sample was taken before seeds were stored (time $=0$ ) and samples were taken at 30, 60, 90, 120, 180240 and 360 days. After sampling, the multi-wall paper bags were placed back in the storage pallets at the same location in the stack.

\section{Seed quality tests}

The initial seed moisture (fresh weight basis) of all samples was determined by drying a $20 \mathrm{~g}$ sample at $105{ }^{\circ} \mathrm{C}$ for 24 hours. Standard germination was examined following the procedures described in the rules for seed testing (Brasil, 1992) using eight replicates of 50 seeds per sample. The accelerated aging test (AA) was conducted following the procedures outlined by Filho (1999), with temperature of $41^{\circ} \mathrm{C}$, near $100 \%$ relative humidity $(\mathrm{RH})$ and duration of 96 hours. The percentage of germination observed in the germination test and in the AA test data were transformed in probit scale (Finney, 1971).

\section{Storage index $(\sigma)$}

The storage index $(\sigma)$ for corn seeds stored in an open warehouse, in Sete Lagoas, State of Minas Gerais, was calculated for all five seed lots as the time taken, in days, for the germination to fall to a certain germination value in the accelerated aging test.

\section{Statistical analysis}

Analysis of variance (ANOVA), the regression analysis and $\mathrm{R}^{2}$ determination for all five seed lots was made by MSTAT (Michigan State University, East Leasing, Michigan) software and it was used to compare the mean differences of the variables.

\section{Results and discussion}

\section{Viability Equation}

The simplified seed viability equation was used to predict the germination per cent of seed lots during storage. The initial germination, the accelerated aging germination, the predicted germination after 180 days, and the slopes of the survival lines are shown in Table 1. There was a high correlation between the actual and the predicted values. The value of $t g b$ for five seed lots was calculated from the storage experiment and the viability curves were plotted (Figure 1). The regression analysis and the slope of the lines as a deterioration rate $(\operatorname{tg} \beta)$ of each seed lot are in Table 1 . The value of the $\operatorname{tg} \beta$ varied from $8.0147 .10^{-4}\left(\mathrm{R}^{2}=0.98\right)$ for lot 02 to $1.3056 .10^{-3}$ $\left(\mathrm{R}^{2}=0.97\right)$ for lot 06 . The equation accurately predicted the viability for all seed lots of corn under open warehouse at Sete Lagoas conditions. Another advantage of this model is that relative humidity is more directly related to water activity, thus it is more relevant to discuss changes in the physiological status of seeds in thermodynamic 
TABLE 1. Performance of initial germination, accelerated aging germination, predicted probit germination after 180 days and the slope $(\operatorname{tg} \beta)$ of five corn seed lots stored in an open warehouse in Sete Lagoas, State of Minas Gerais. Seeds were initially stored on July 04, 1998.

\begin{tabular}{cccccc}
\hline Seed Lot & $\begin{array}{c}\text { Germination } \\
(\mathbf{\%})\end{array}$ & $\begin{array}{c}\text { Aging Test } \\
\mathbf{( \% )}\end{array}$ & $\begin{array}{c}\text { Probit Germination } \\
\text { after } \mathbf{1 8 0} \text { days, }(\%)\end{array}$ & $\begin{array}{c}\text { Slope }(\operatorname{tg} \beta) \text { of the } \\
\text { survival curves }\end{array}$ & $\mathbf{R}^{\mathbf{2}}$ \\
\hline Lot 02 & 92 & 89.6 & $1.2462(89.2)$ & $-8.0147 .10^{-4}$ & 0.98 \\
Lot 03 & 93 & 90.8 & $1.2948(90,2)$ & $-1.3056 .10^{-3}$ & 0.97 \\
Lot 04 & 95 & 92.8 & $1.4159(92.0)$ & $-1.4972 .10^{-3}$ & 0.98 \\
Lot 06 & 98 & 96.2 & $1.6931(95.4)$ & $-2.0031 .10^{-3}$ & 0.97 \\
Lot 07 & 96 & 93.0 & $1.5703(94,2)$ & $-1.5029 .10^{-3}$ & 0.99 \\
\hline
\end{tabular}

${ }^{1}$ The slope of the survival curves (seed deterioration rate $=t g b$ ) was calculated by the model $V t=V i-t g b . p$, where $V t$ is the probit germination at the time $p, V i$ is the probit germination at time $=0$.

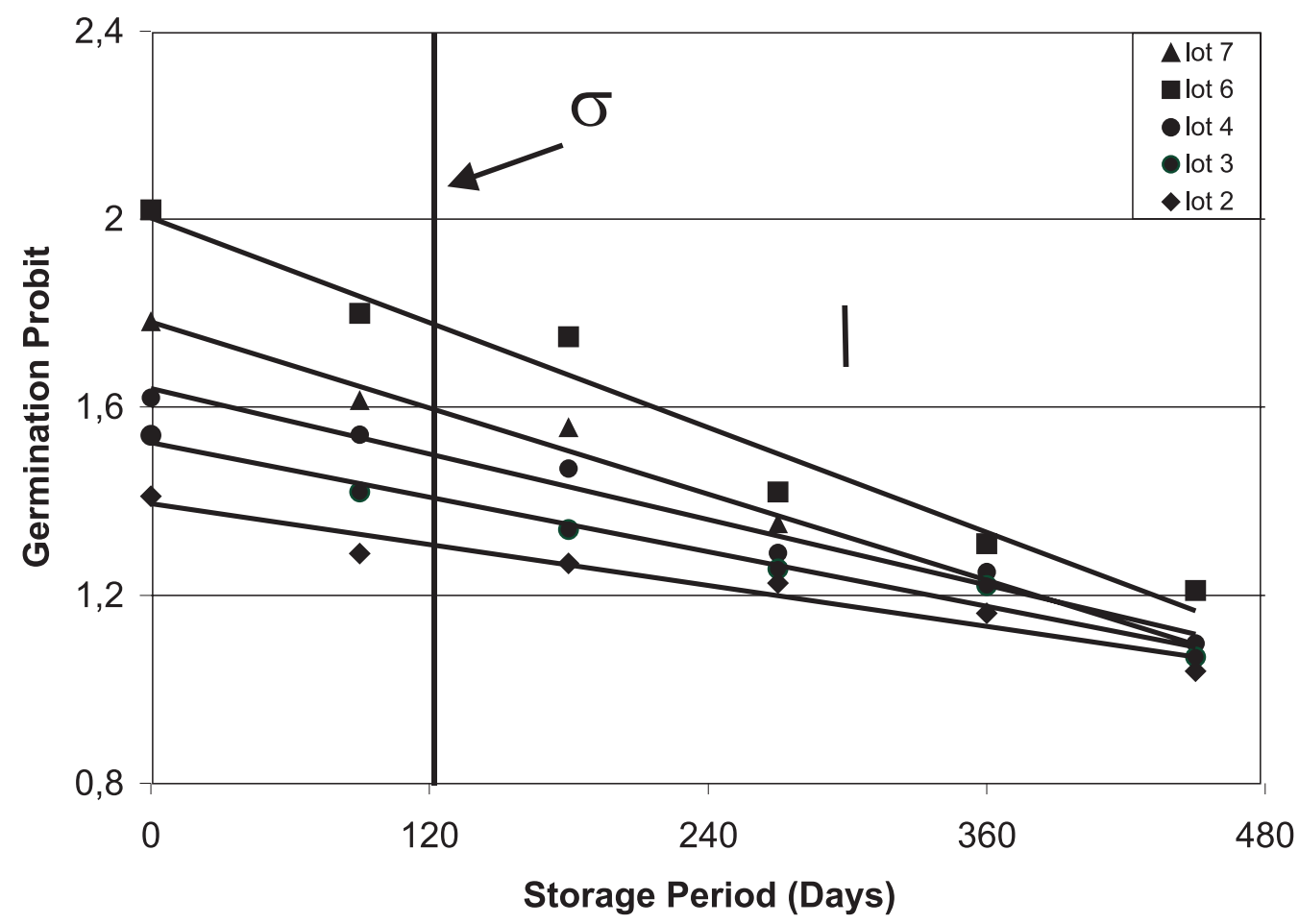

FIGURE 1. The value of storage index $(\sigma)$ of five seed lots of maize seeds stored in Sete Lagoas, State of Minas Gerais in an open warehouse. The index value of $\sigma=120$ days, for these seed lots, corresponds to the time taken in days for the germination of corn seeds to reach a similar value observed in the accelerated aging test. Bar denotes $\mathrm{LSD}_{0.05}$ 
terms than by seed moisture (Vertucci \& Roos, 1990, 1993; Vertucci et al. 1994). It is important to note also that Ellis \& Roberts' equation predicts seed viability of the species and the simplified model estimates the seed deterioration rate of seed lots.

Based on the data of germination and aging test of the five seed lots, the storage index $(\sigma)$ was calculated specifically for Sete Lagoas conditions. The storage index value is unique for each species and environmental condition (temperature and relative humidity of the warehouse), but independent of the initial quality of the seed and the genotypes (Andreoli, 1998, 2004; Ellis et al. 1991). The estimates of $\sigma$ for corn seed lot provided by probit analysis are shown in Figure 1. The storage index value of
120 days was determined for all five seed lots stored in an open warehouse in Sete Lagoas, State of Minas Gerais (Figure 1). This $\sigma$ value corresponded to the time taken, in days, for germination of all five seed lots to fall during storage to the same germination value in the accelerated aging test at $42^{\circ} \mathrm{C}$ and $100 \%$ R.H. The seed deterioration values change depending upon the environmental conditions of the warehouse, so under unfavorable storage condition (high temperatures and $\mathrm{RH}$ ), the storage index value $(\sigma)$ tends to be lower and vice-versa.

\section{Seed Longevity Chart}

Based upon the data of this trial, a seed longevity chart was built up (Figure 2). It illustrates the relationship between initial

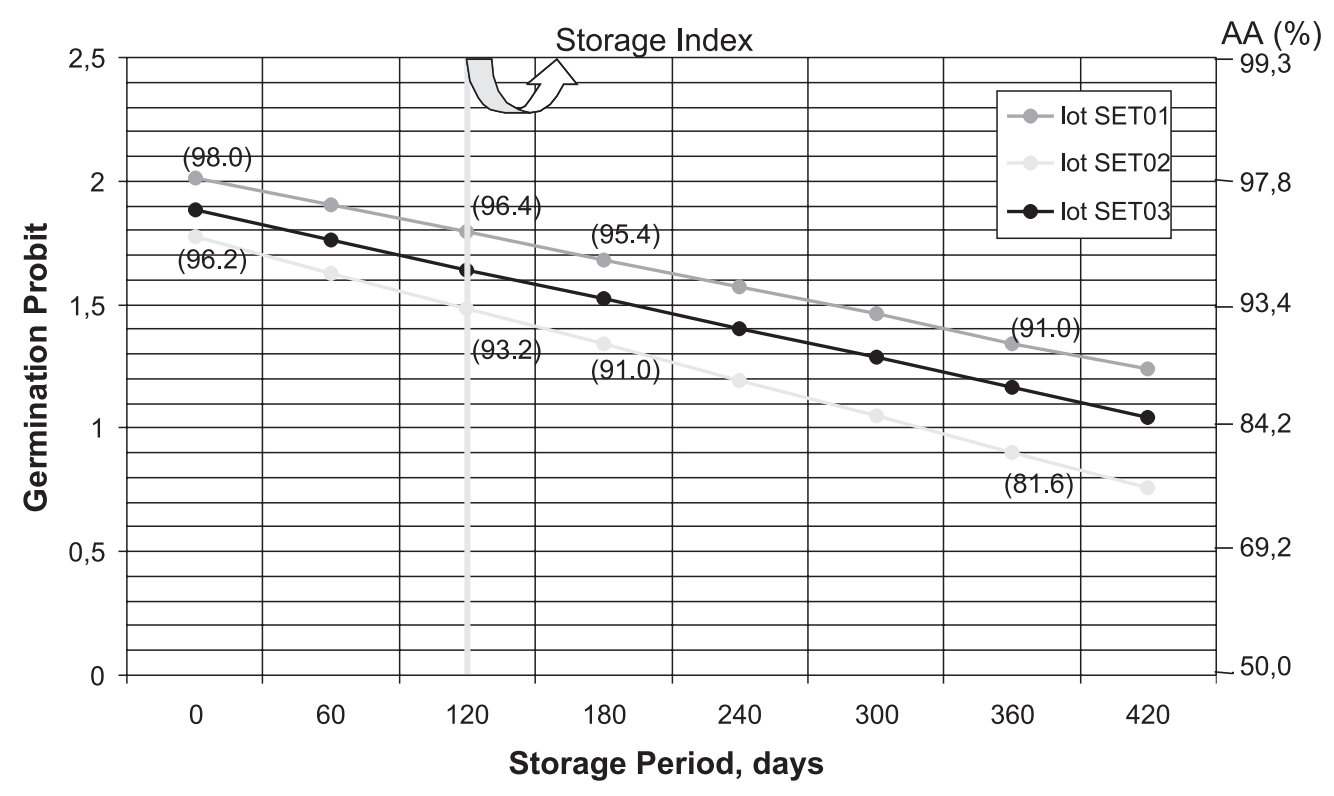

FIGURE 2. Seed longevity chart to predict and monitor corn seed lots during storage. For predicting the viability of corn seed lots, the initial probit germination (time $=0$ ) is placed on left axis Y and the accelerated aging germination are placed on the right axis. The storage line perpendicular line to the axis $X(p)$ at 120 days is drawn in the chart. The AA value is, then, moved towards the left till the line of the storage index $(\sigma=120$ days $)$ is found. By connecting these two points, a straight line can be drawn and the viability of seed lots over a period of time might be predicted. The numbers in parenthesis at time $=0$ day are the initial germination, at 120 days are the AA germination and the predicted values after 180 and 360 days for seed lot SET01 and lot SET03 stored in Sete Lagoas, in 1999. 
germination, seed deterioration rate and storage conditions over time. This trial attempted to design a model in which seeds, exposed to actual temperatures and $\mathrm{RH}$ in an open warehouse, could have their longevity predicted by plotting the storage index value $(\sigma)$, the initial germination and the aging test in a longevity chart as shown in the Figure 2.

To use the chart, the value of $V i$ (initial probit germination) at time zero should be placed on the left of vertical axis scale and the value of the AA test on the right axis. The storage index line at 120 days should be drawn perpendicular to the axis line $\mathrm{X}(p)$. A ruler is now placed on the AA scale and moved towards the left till the s value (120 days) is found. Finally, by connecting these two points, a straight line can be drawn and the viability of a seed lot over a period of time might be predicted (Figure 2). The chart can be used by any seed producer once the value of storage index $(\sigma)$ in situ is determined for each species. For instance, a seed producer determines the storage index for corn as 120 days at his warehouse and wishes to predict the viability loss of the seed lots during storage. For testing the model, seed lots of corn harvested in 1999, with initial germination of $98.0 \%$ and aging test of $96.4 \%$, were transformed to probit scale that correspond to 2.0537 and 1.7991 , respectively. After plotting the initial germination (2.0537) on left axis and the aging test value $(96.4 \%=$ probit 1.7991) on right axis of the chart on Figure 2, the later was moved horizontally to the left until the perpendicular line (storage index) is found. By connecting these two points, a straight line can be drawn and the viability of this seed lot can be predicted over time. For validation of the seed longevity chart, two corn seed lots were stored in Sete Lagoas, MG. As shown in the Figure 2, the seed lot SET01, with initial germination of 98.0 per cent, falls to 95.4 and 91.0 percent after 180 and 360 days, respectively, stored at that particular condition. In the same period, at these conditions the viability of another seed lot SET03 with 96.2 $\%$ germination initially and AA test of $93.2 \%$ falls to 91.0 and 81.6 per cent, respectively (Figure 2). Crossing the data of Table 1 and Figure 2 , we can note that the observed and predicted values are closely related (mean $\mathrm{R}^{2}>0.97$ ), confirming the predictive model of the simplified equation proposed by Andreoli (1998). Furthermore, the seed longevity chart also takes into account variations in vigor among seed lots. Let us consider two seed lots with initial germination (time $=0$ days) of 95 per cent, and vigor of 90 and 86 percent. Placing the probit values in the chart (Figure 2), the germination of these two seed lots falls to 86.5 and 77.5 percent after 180 days of storage (data not plotted). This means that the seed longevity chart is a good tool to monitor seed lots even before storage and that low vigor seed lots could be discarded before packing, saving labor, money, and space in the seed warehouse.

In this paper we emphasize the validation of the seed longevity chart to the seed producers and farmers where seed deterioration related to the warehouse storage can be predicted with confidence. The seed longevity chart has proved to be a worthy tool for seed producers in managing and monitoring seed lots during storage.

This viability chart is simple, reliable and it can be applied with confidence to any particular seed lot. Moreover, there is no need for estimating the constants of the viability equation (Ellis \& Robersts, 1980) for each seed lot and the climatic data of the warehouse do not need to be recorded as described by Tekrony et al. (1993). Yet, it takes into account variations in seed quality before and 
during storage resulting from environmental factors.

The data suggest that the application of the seed viability chart for short storage conditions seems to be promising for seed growers. This seed deterioration predictive model is the first attempt that has incorporated the effects of seed quality, temperature and relative humidity into a seed longevity chart in an open storage.

\section{Acknowledgements}

This research was supported in part by a grant from CNPq Project no.301809/95 (RN) and Embrapa Project no. 04.0.94.264.04.

\section{Literature Cited}

ABDALLA, F. H.; ROBERTS, E. H. Effects of temperature, moisture, and oxygen on the induction of chromosome damage in seeds of barley, broad beans and peas during storage. Annals of Botany, v. 32, p. 119-36, 1968.

ANDREOLI, C. The simplified equation to predict storability of maize and soybean seeds. In INTERNATIONAL CONFERENCE ON SEED SCIENCEAND TECHNOLOGY, 2, 1998, Guangzhou. Progress in seed research: procedings... Geneva: New York State Agricultural Experiment Station, p. 186-198, 1998. Edited by A. G. Taylor, Huang, X. L.

ANDREOLI, C. Simplificação da equação de viabilidade para predizer a longevidade da semente de milho e soja. Pesquisa Agropecuária Brasileira, Brasília, v. 39, n. 9, p. 911-917, 2004.

BRASIL. Ministério da Agricultura, Abastecimento e Reforma Agrária. Regras para Análise de Sementes. Brasília: SNAD/DNDV/CLAV, 1992. 365p.
BURRIS, J.S. Maintenance of soybean seed quality in storage as influenced by moisture, temperature and genotype. Iowa State Journal of Research, Des Moines, v. 54, p. 377-389, 1980.

DELOUCHE, J.C.; BASKIN, C.C. Accelerated aging techniques for predicting the relative storability of seed lots. Seed Science and Technology, Zurique, v. 1, p. 427-452, 1973.

ELLIS, R.H.; ROBERTS, E.H. Improved equations for the prediction of seed longevity. Annals of Botany, Londres, v. 45, p. 13-30, 1980.

ELLIS, R.H.; HONG, T.D.; ROBERTS, E.H. Seed moisture content, storage, viability and vigor (Correspondence). Seed Science Research, Londres, v. 1, p. 275-279, 1991.

FINNEY, D.J. Probit analysis. 3rd edition. Cambridge University Press, London, 1971, $318 \mathrm{p}$.

FILHO, J.M. Teste de envelhecimento acelerado. In: KRZYZANOWSKI, F.C.; VIEIRA, D. R.; FRANÇA NETO, J.B. (Ed.). Vigor de sementes: Conceitos e testes. Londrina: Associação Brasileira de Tecnologia de Sementes, 1999. p.3.1-3.24.

ROBERTS, E.H. The viability of cereal seed in relation to temperature and moisture. Annals of Botany, Londres, v. 24, p. 12-31, 1960.

ROBERTS, E.H. The viability of rice seed in relation to temperature, moisture content and gaseous environment. Annals of Botany, Londres, v. 25, p. 381-90, 1961. 
ROBERTS, E.H. Predicting the storage life of seeds. Seed Science and Technology, Zurique, v. 1, p. 499-514, 1973.

TEKRONY, D. M.; NELSON, C.; EGLI, D. B.; EGLI, G. M. Predicting soybean seed deterioration during warehouse storage. Seed Science and Technology, Zurique, v. 21, p. 127-137, 1993.

VERTUCCI, C.W.; ROOS, E.E. Theoretical basis of protocols for seed storage. Plant Physiology, Rockville, v. 94, p. 1019-1023, 1990.
VERTUCCI, C.W.; ROOS, E.E. Seed storage temperature and relative humidity (correspondence). Seed Science Research, Londres, v. 3, p. 215-216, 1993.

VERTUCCI, C. W.; ROOS, E. E.; CRANE, J. Theoretical basis of protocol for seed. III. Optimum moisture contents for pea seeds stored at different temperatures. Annals of Botany, v. 74, p. 531-540, 1994. 